\title{
Marine bacteria from the French Atlantic coast displaying high forming-biofilm abilities and different biofilm 3D architectures
}

Ibtissem Doghri', Sophie Rodrigues², Alexis Bazire², Alain Dufour ${ }^{2}$, David Akbar', Valérie Sopena ${ }^{1}$, Sophie Sablé ${ }^{\text {* }^{+}}$and Isabelle Lanneluc ${ }^{1+}$

\begin{abstract}
Background: Few studies have reported the species composition of bacterial communities in marine biofilms formed on natural or on man-made existing structures. In particular, the roles and surface specificities of primary colonizers are largely unknown for most surface types. The aim of this study was to obtain potentially pioneering bacterial strains with high forming-biofilm abilities from two kinds of marine biofilms, collected from two different surfaces of the French Atlantic coast: an intertidal mudflat which plays a central role in aquaculture and a carbon steel structure of a harbour, where biofilms may cause important damages.

Results: A collection of 156 marine heterotrophic aerobic bacteria isolated from both biofilms was screened for their ability to form biofilms on polystyrene 96-well microtiter plates. Out of 25 strains able to build a biofilm in these conditions, only four bacteria also formed a thick and stable biofilm on glass surfaces under dynamic conditions. These strains developed biofilms with four different three - dimensional architectures when observed by confocal laser scanning microscopy: Flavobacterium sp. II2003 biofilms harboured mushroom-like structures, Roseobacter sp. IV3009 biofilms were quite homogeneous, Shewanella sp. IV3014 displayed hairy biofilms with horizontal fibres, whereas Roseovarius sp. VA014 developed heterogeneous and tousled biofilms.

Conclusions: This work led for the first time to the obtaining of four marine bacterial strains, potentially pioneering bacteria in marine biofilms, able to adhere to at least two different surfaces (polystyrene and glass) and to build specific 3D biofilms. The four selected strains are appropriate models for a better understanding of the colonization of a surface as well as the interactions that can occur between bacteria in a marine biofilm, which are crucial events for the initiation of biofouling.
\end{abstract}

Keywords: Marine bacteria, Biofilm, Abiotic surfaces, Biofilm 3D structures

\section{Background}

Biofilms are generally considered as surface-associated microorganism communities encased in a hydrated polymeric matrix [1]. In marine environment, most of the solid man-made structures as well as natural surfaces are covered by microbial biofilms. Together with diatoms, bacteria constitute the major components of biofilms occurring in the marine environment [2]. Furthermore, all types of bacteria can form biofilms, making this sedentary

\footnotetext{
* Correspondence: sophie.sable@univ-Ir.fr

'Equal contributors

'Université de La Rochelle, UMR 7266 CNRS-LIENSs, Bât. Marie Curie, Av. Michel Crépeau, 17042, La Rochelle cedex 01, France

Full list of author information is available at the end of the article
}

lifestyle their favourite mode of existence in nature [3]. This mechanism is described as considerably important for survival of marine bacteria by providing a favourable environment [4]. This lifestyle, compared to the planktonic one, indeed improves access to nutrients and protects against stress, antibiotics and predators $[1,5]$.

Quickly after immersion of a clean surface in the sea, microorganisms colonize it and subsequently develop biofilms with highly diverse three-dimensional (3D) structures which can include channels allowing the flow of liquids, nutrients and wastes [6-8]. The early stages of biofilm formation are based on the interactions of free-living bacteria with the surface which generates an 
initial layer of microorganisms and polymers [5]. Thereafter, growth of the primary colonizing bacteria changes the surface characteristics of the substratum, rendering it suitable for subsequent colonization by other microorganisms. Finally, the mature biofilm community is formed through synergistic and/or competitive interactions [5].

Few studies have reported the species composition of bacterial communities in marine biofilms. In particular, the roles and surface specificities of primary colonizers are largely unknown for most surface types [9]. The early-stage biofilms were dominated by the same major classes of bacteria that were most abundant in planktonic communities, with the latter demonstrating a higher diversity when compared with that of biofilm bacteria $[9,10]$. The Alphaproteobacteria and Gammaproteobacteria were recognized as the pioneering microorganisms in marine biofilm formation [2, 5, 9-11]. Then, Acidobacteria, Actinobacteria, Bacteroidetes, Chloroflexi, Cyanobacteria, Firmicutes, Planctomycetes, Verrucomicrobia and Beta, Delta and Epsilon groups of Proteobacteria were identified as minor phyla also belonging to these biofilms [5, 8-10, 12-14]. However, the bacterial composition of early-stage biofilms may be affected by the physicochemical properties of the solid surface $[5,10]$ and by the variation of environmental conditions due for example to the seasons or the characteristics of the immersion sites [2].

In the present work, we studied bacteria of two original types of marine biofilms from the French Atlantic coast, displaying different characteristics. The first one is a non-permanent benthic biofilm sampled from an intertidal mudflat, which plays a central role in the production of oysters. Indeed, oyster larvae can directly digest and assimilate bacterial carbon [15]. Moreover, this biofilm indirectly feeds the planktonic trophic network through re-suspension of the biofilm in the water column. However, current knowledge on the structure as well as the functioning of this biofilm is largely conceptual and theoretical. The second one is a permanent biofilm formed on carbon steel structures immersed in a French Atlantic harbour and involved in the early stages of the biocorrosion phenomenon [16]. In seawater, complex biofilms closely linked with corrosion products quickly develop on metallic structures. This can influence the deterioration of metal by microorganism activity, thus causing great damages to harbour infrastructures, resulting in economic losses. To date, the initiation of the microbiologically-influenced corrosion processes remains unclear.

Understanding the initial stage of marine biofilm formation is highly important to explain the biofilm formation phenomenon. Unlike the studies in which the structure of pioneering communities, developed on immersed artificial surfaces in seawater, is directly investigated [9, 14], our approach was first to build a collection of culturable marine bacteria isolated from two kinds of biofilms and then to screen for the ability of each isolate to adhere to artificial surfaces and to form biofilms under the same controlled conditions. The objective of this work was to obtain model strains with high forming-biofilm abilities, suitable for further experiments which would allow a better understanding of the colonization of a surface as well as the interactions that can occur between bacteria in a marine biofilm.

\section{Results}

\section{Screening of bacteria for their ability to adhere and to form biofilms on polystyrene surfaces}

In order to efficiently select strains able to adhere and to form biofilms, the whole bacterial collection of 156 heterotrophic aerobic bacteria, isolated as described in the "Methods" section, was first screened with a rapid method, based on crystal violet staining of biofilms formed in 96-well microtiter plates (polystyrene surfaces). The bacteria that efficiently formed biofilms onto this surface after a $2 \mathrm{~h}$ adhesion step and $24 \mathrm{~h}$ of growth were identified by $16 \mathrm{~S}$ rDNA sequencing. This screening revealed that the biofilm formation ability was very variable according to the bacterial strains (Fig. 1).

Under our experimental conditions, out of 86 isolates from the intertidal mudflat biofilms, 15 strains were able to form a biofilm with a ratio of cel1s grown in biofilm/ planktonic cells higher than 2 (Fig. 1). These biofilmforming bacteria were distributed in 5 bacterial classes: Flavobacteriia (27 \%), Gammaproteobacteria (27 \%), Alphaproteobacteria (20\%), Bacilli (20\%) and Actinobacteria (6 \%). The Flavobacterium sp. II2003 strain, with a ratio of 13 , showed the best ability to form a biofilm on polystyrene. Other bacteria displayed a strong ability to form a biofilm on polystyrene: Postechiella sp. I4003, Roseobacter sp. I4016 and IV3009 and Shewanella sp. IV3014 showed a ratio higher than 8 (Fig. 1). The proportion of benthic bacterial strains able to form biofilms according to the sampling time at low tide is presented in Fig. 2a. Bacteria forming a biofilm were found at all emersion times (from 2 to $4 \mathrm{~h}$ ). However, when less than 10 strains were isolated from a sample, no biofilm-forming bacterium was detected in this sample, whatever the emersion time (Fig. 2a).

Concerning the bacteria isolated from biofilms developed on corroded carbon steel immersed in sea water, 10 strains among the 70 isolates were able to form biofilms after $24 \mathrm{~h}$ (with a ratio of cells grown in biofilm/ planktonic cells higher than 2) (Fig. 1). These strains were affiliated to the same taxonomic groups as the benthic bacteria, but the proportion of bacteria from each 


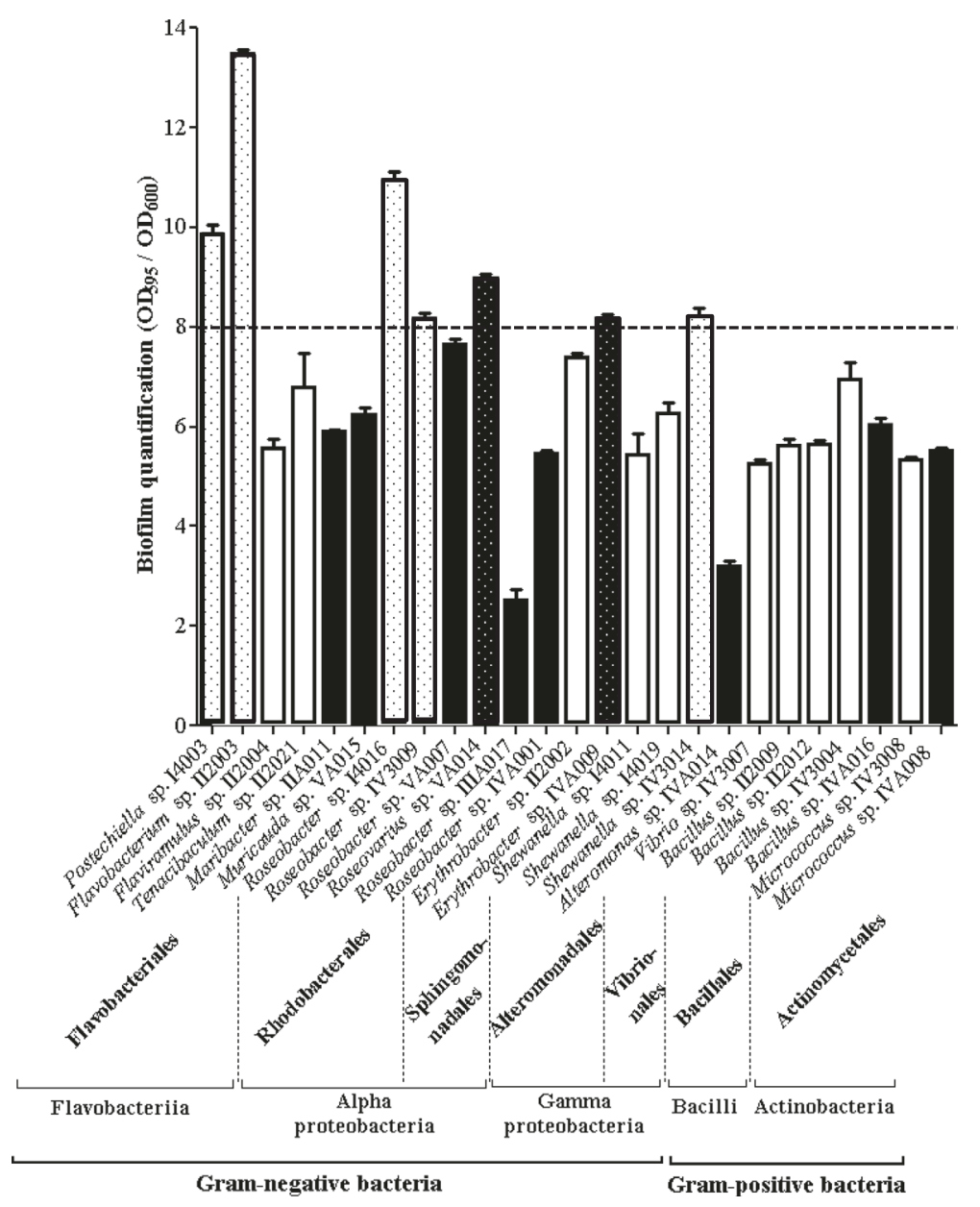

Fig. 1 Quantification of bacterial biofilm formation on polystyrene microtiter plates under static conditions. Bacteria were isolated from intertidal mudflat biofilms (white bars) and from corrosion product-microorganism composite biofilms developed on harbor metallic structures (black bars). After $24 \mathrm{~h}$ of growth, single-species biofilms were quantified with crystal violet and the ratios of $\mathrm{OD}_{595}$ (cells grown in biofilm)/OD 600 (planktonic cells) were calculated. The ratios are represented on the $y$ axis. Dotted bars: bacteria with a ratio $\mathrm{OD}_{595} / \mathrm{OD}_{600}>8$. Bars represent means \pm standard deviations for three replicates

class varied: $50 \%$ Alphaproteobacteria, $20 \%$ Flavobacteriia, $10 \%$ Gammaproteobacteria, $10 \%$ Bacilli and $10 \%$ Actinobacteria. Under our experimental conditions, the ratios of cel1s grown in biofilm/planktonic cells obtained for these bacteria were lower than for the benthic bacteria. The ratio of 9, for the Roseovarius sp. VA014 strain, was the highest value obtained for bacteria isolated from corroded structures (Fig. 1). Erythrobacter sp. IVA009 was also interesting with a ratio higher than 8 (Fig. 1). The results presented in Fig. 2b show that bacteria able to form a biofilm on polystyrene were found in all samples, but the highest number was isolated from the steel immersed for 2 weeks.

In conclusion, this first screening allowed us to detect 15 benthic bacteria and 10 bacteria from corroded structures able to develop a biofilm in 96-well polystyrene microplates.
Ability of the selected strains to adhere and to form biofilms under static conditions on glass surfaces

The above screening method in polystyrene microplates was rapid and convenient to detect the bacterial ability to form biofilms, but did not provide any structural information on these biofilms. To get this kind of information and thus study more accurately stable biofilms, the experiments had to be performed in dynamic conditions with biofilm observation by confocal laser scanning microscopy. Such observations required glass surfaces, and it was uncertain whether strains able to develop a biofilm on polystyrene would also be able to do it on glass. Since the biofilm study in dynamic conditions was labour intensive and time consuming, all bacteria that formed biofilms on polystyrene were then screened for their ability to form a biofilm on glass surfaces, first of all in static conditions. After a $2 \mathrm{~h}$ adhesion step and $24 \mathrm{~h}$ of growth, 


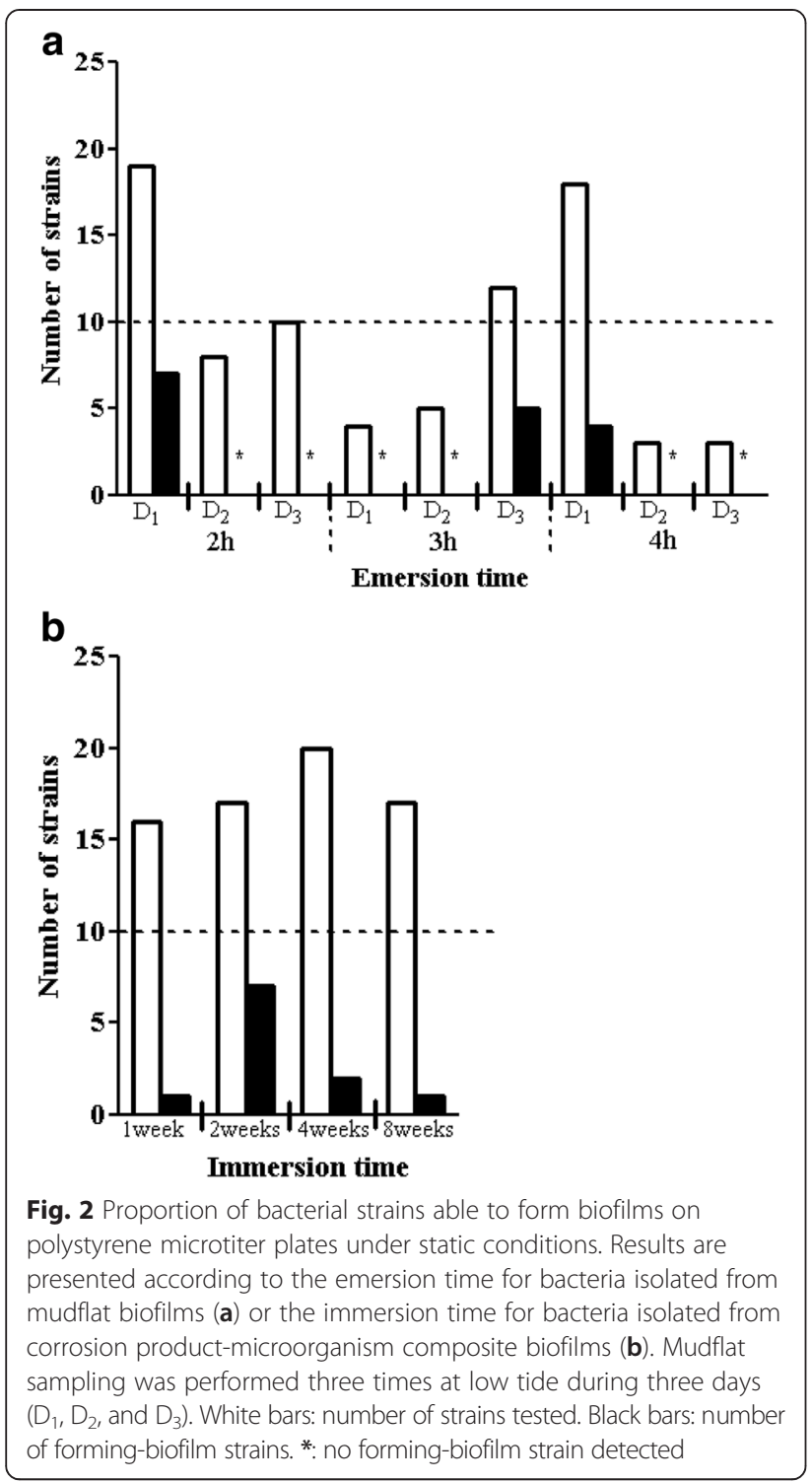

the biofilm was stained with DAPI, and microscopic fluorescence observations were performed to detect the strains behaviour on the glass surface. Among the previously selected bacteria (15 benthic bacteria and 10 bacteria isolated from corroded structures), only the Postechiella sp. I4003, Flavobacterium sp. II2003, Flaviramulus sp. II2004, Roseobacter sp. IV3009 and Shewanella sp. IV3014 benthic bacteria and the Roseobacter sp. IIIA017 and Roseovarius sp. VA014 strains from corroded structures were able to form biofilms under these conditions (Fig. 3). Microscopic observations of their biofilms showed a high percentage of colonized surfaces, from $42.5 \%$ for Postechiella sp. I4003 to $76 \%$ for Roseobacter sp. IV3009 (Fig. 3a). On the bases of the biofilm structures, two types of biofilms could be distinguished (Fig. 3a). The Postechiella sp. I4003, Flavobacterium sp. II2003 and Roseobacter sp.
IV3009 biofilms were very heterogeneous and contained large cell aggregates whereas the Roseobacter IIIA017, Roseovarius sp. VA014, Flaviramulus sp. II2004 and Shewanella sp. IV3014 biofilms contained more evenly distributed cells. To classify the strains, bacteria were gathered when they exhibited no significant biofilm thickness differences. Thus, Flavobacterium sp. II2003, Roseobacter sp. IV3009, Shewanella sp. IV3014 and Roseovarius sp. VA014 were grouped. They built significantly thicker biofilms $(40.2 \mu \mathrm{m}, 33.8 \mu \mathrm{m}, 34 \mu \mathrm{m}$ and $31.1 \mu \mathrm{m}$ respectively, Fig. $3 \mathrm{~b})$. Roseobacter sp. IIIA017 and Flavobacterium sp. I4003 biofilms were significantly thinner than all other biofilms, with an average of $16.4 \mu \mathrm{m}$ and $19.8 \mu \mathrm{m}$ respectively (Fig. $3 \mathrm{~b}$ ), and formed another group. Finally, Flaviramulus sp. II2004 biofilm exhibited an intermediate average thickness $(24.2 \mu \mathrm{m})$, significantly different from all other strain biofilms (Fig. 3b).

\section{Study of the bacterial biofilm structures under dynamic conditions in flow cells}

Through the previous steps, seven bacteria have been selected for their capability to form a thick biofilm under static conditions on polystyrene as well as glass surfaces. These bacteria were then studied under dynamic conditions, to further investigate strains able to develop stable biofilms. Thus, bacterial biofilms were grown on glass slides in three-channel flow cells and observed by confocal laser scanning microscopy after staining with the Syto 61 fluorescent dye.

The seven strains were able to attach onto the glass slide during a $2 \mathrm{~h}$ adhesion step in artificial seawater without flow, but the biofilms of three strains were not sufficiently stable and only four strains (Flavobacterium sp. II2003, Roseobacter sp. IV3009, Shewanella sp. IV3014 and Roseovarius sp. VA014) were able to form biofilms after $24 \mathrm{~h}$ of growth under a continuous culture medium flow. The microscopic observations of these strains are shown in Figs. 4 and 5. After the adhesion step, Flavobacterium sp. II2003, Shewanella sp. IV3014 and Roseovarius sp. VA014 began to form aggregates or microcolonies, whereas Roseobacter sp. IV3009 cells were more individually attached (Fig. 4). Roseovarius sp.VA014 cells were more filamentous. About $25 \%$ of the glass surfaces were covered for all strains, except for the Roseobacter sp. IV3009 strain, which exhibited a significantly $(p<0.05)$ lower percentage of colonized surface (16\%, Fig. 4). After $24 \mathrm{~h}$ of biofilm growth, four different 3D architectures were observed (Fig. 5). Flavobacterium sp. II2003 biofilms harbouring numerous mushroom-like structures with a non-uniform distribution are reminiscent of biofilms of the well-known Pseudomonas aeruginosa model [17, 18].

The Flavobacterium sp. II2003 biofilms presented significantly higher maximal thicknesses compared to 


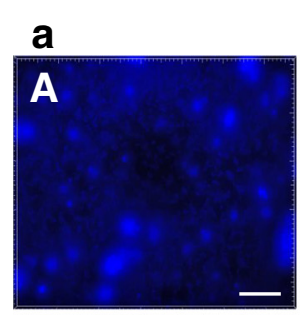

Postechiella sp. I 4003 CP: $42.5 \%$

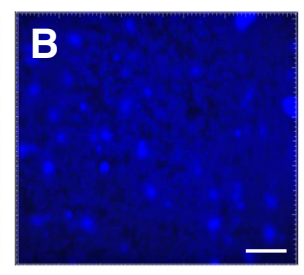

Flavobacterium sp. II2003 CP. $71 \%$

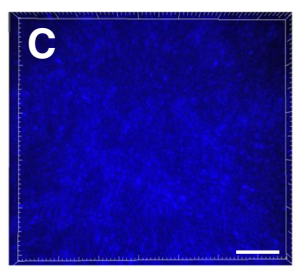

Flaviramulus sp. II 2004 CP: $62 \%$

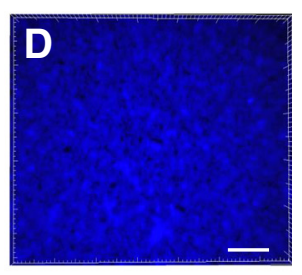

Roseobacter sp.

IV3009

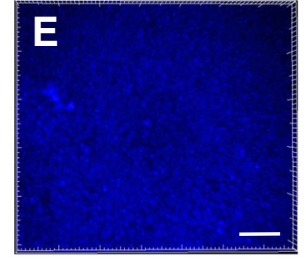

Shewanella sp. IV3014 CP: $60 \%$

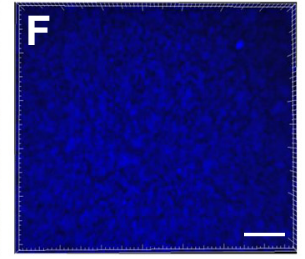

Roseobacter sp.

IIIA017

CP: $60 \%$

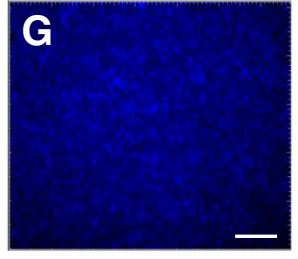

Roseovarius sp.

VA014

CP: $68.5 \%$

b

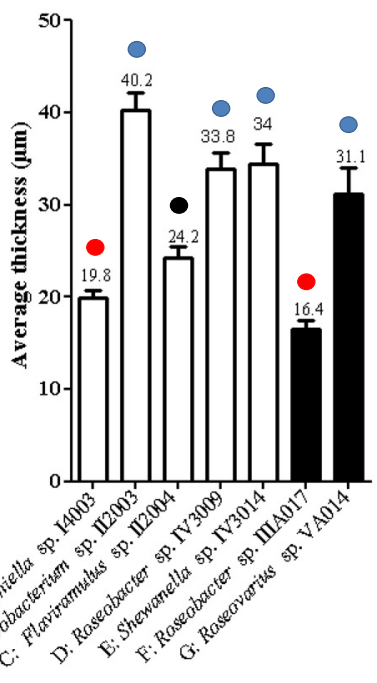

\begin{tabular}{lccccccc}
\hline & $\mathrm{A}$ & $\mathrm{B}$ & $\mathbf{C}$ & $\mathrm{D}$ & $\mathrm{E}$ & $\mathrm{F}$ & $\mathrm{G}$ \\
\hline $\mathrm{A}$ & - & $* * *$ & $*$ & $* *$ & $*$ & $\mathrm{~ns}$ & $*$ \\
\hline $\mathrm{B}$ & & - & $* *$ & $\mathrm{~ns}$ & $\mathrm{~ns}$ & $* * *$ & $\mathrm{~ns}$ \\
\hline $\mathbf{C}$ & & & - & $*$ & $*$ & $* * *$ & $*$ \\
\hline $\mathrm{D}$ & & & & - & $\mathrm{ns}$ & $* * *$ & $\mathrm{~ns}$ \\
\hline $\mathrm{E}$ & & & & & - & $* *$ & $\mathrm{~ns}$ \\
\hline $\mathrm{F}$ & & & & & & - & $* *$ \\
\hline $\mathrm{G}$ & & & & & & & - \\
\hline
\end{tabular}

Statistical significance of biofilm thickness differences among strains $A$ to $G$

Fig. 3 Fluorescence microscopic 3D reconstitutions and quantification of biofilms formed on glass surfaces under static conditions. After $24 \mathrm{~h}$ of growth under static conditions, biofilms were stained with DAPI. Microscopic 3D images were reconstituted (a), the average thicknesses of the biofilms were determined and the differences between them were statistically tested (b). A, B, C, D, E: bacterial isolates from mudflat biofilms. F, G: bacterial isolates from corrosion product-microorganism composite biofilms. Scale bar: $200 \mu \mathrm{m}$. CP: percentage of colonized surface. These values are averages of data from three independent experiments, with standard deviations lower than $10 \%$ of each value. ${ }^{*}: p<0.05$; **: $p<0.01$; ***: $p<0.001$. ns: not significant. Circles with the same color indicate bacteria with no significant biofilm thickness differences. Blue circles: thickest biofilms. Red circles: thinnest biofilms. Black circle: intermediate thickness

biofilms of the three other strains, due to the mushroomlike structures, but their average thicknesses were only significantly higher than those of the Shewanella sp. IV3014 biofilms (Fig. 6). Shewanella sp. IV3014 displayed hairy biofilms with horizontal fibres, whereas Roseovarius sp. VA014 developed heterogeneous and tousled biofilms with cell aggregates (Fig. 5). Roseobacter sp. IV3009 biofilms were quite homogeneous with a bacterial distribution covering the entire surface (Fig. 5). The average and maximal thicknesses of Roseobacter sp. IV3009 biofilms were the same $(10 \mu \mathrm{m}$, Fig. 6), confirming the regular distribution of cells. No significant differences were observed between Shewanella sp. IV3014, Roseovarius sp. VA014 and Roseobacter sp. IV3009 for the average and the maximal biofilm thicknesses (Fig. 6). Similarly, the biovolumes of all 4 biofilms were not significantly different from each other. 


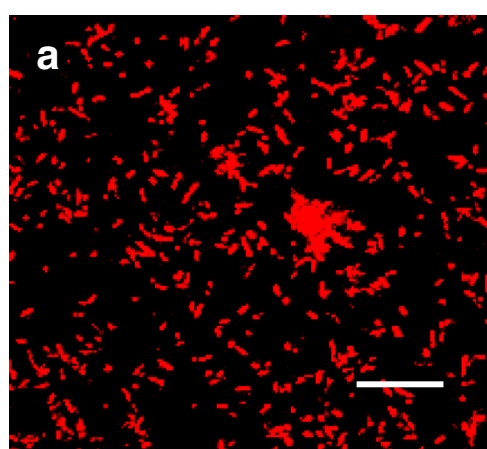

Flavobacterium sp. II2003

CP: $25 \%$

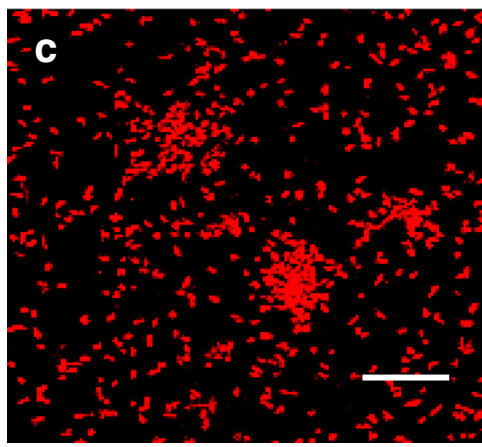

Shewanella sp.

IV3014

CP: $25 \%$

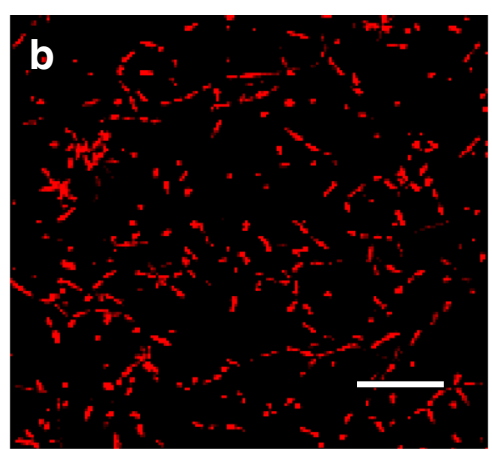

Roseobacter sp.

IV3009

CP: $16 \%$

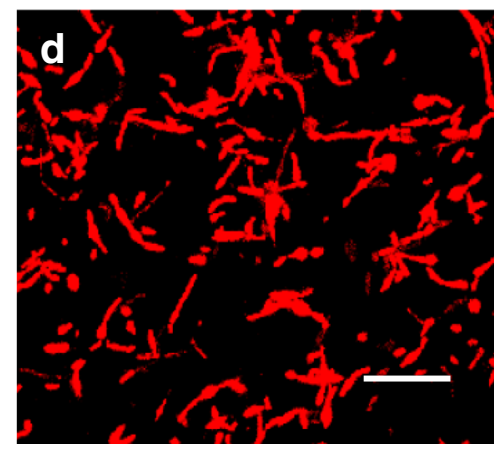

Roseovarius sp.

VA014

CP: $25 \%$

Fig. 4 Confocal laser scanning microscopy images of attached cells after $2 \mathrm{~h}$ of adhesion on glass surfaces. Bacteria were allowed to attach into the flow cells during $2 \mathrm{~h}$ in artificial seawater without flow. Syto 61 red was used to stain the attached cells. $\mathbf{a}$, b, c: bacterial isolates from mudflat biofilms. $\mathbf{d}$ : bacterial isolate from corrosion product-microorganism composite biofilms. Scale bar: $47 \mu m$. CP: percentage of colonized surface. These values are averages of data from three independent experiments, with standard deviations lower than $10 \%$ of each value

In conclusion, only four strains, Flavobacterium sp. II2003, Roseobacter sp. IV3009, Shewanella sp. IV3014 from the mudflat and Roseovarius sp. VA014 from the steel structure, were able to develop a stable singlespecies biofilm under dynamic conditions. Each biofilm had a specific structure. Interestingly, these strains were the four bacteria that displayed the thickest biofilms (more than $30 \mu \mathrm{m}$ ) on glass surfaces under static conditions (Fig. 3b).

\section{Discussion}

In this work, we studied bacteria that inhabited two types of marine biofilms. Out of 156 isolates of our marine bacterial collection, only 15 strains from the mudflat biofilms and 10 strains from the corroded metallic structures were able to form single-species biofilms on polystyrene surfaces. This low number of biofilm forming bacteria could be explained by the experimental conditions. For instance, monospecies biofilms were performed, whereas in natural environments, the presence of different bacteria may help to build a biofilm. Moreover, the substratum we used differed from that of the original ecosystem, and the time we let for the bacteria to attach to their support was $2 \mathrm{~h}$ only. This step was particularly relevant for pioneer bacteria known to settle in few hours in marine biofilms [9]. Cell density, medium, temperature... may also influence the biofilm formation.

Among our marine cultured strains collection, the most important bacterial classes able to form a biofilm in microtiter polystyrene plates were Alphaproteobacteria ( 5 from the steel and 3 from the mudflat, of which 6 were Rhodobacterales), Flavobacteriia (4 from the mudflat and 2 from the steel, all being Flavobacteriales), Gammaproteobacteria (4 from the mudflat and 1 from the steel, of which 4 Alteromonadales) and Bacilli (3 from the mudflat 


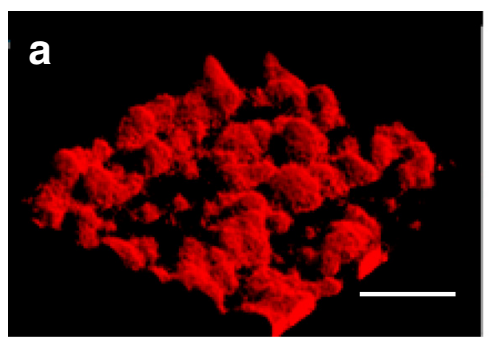

Flavobacterium sp. II2003

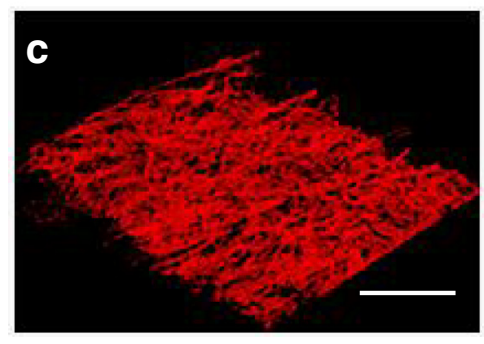

Shewanella sp. IV3014

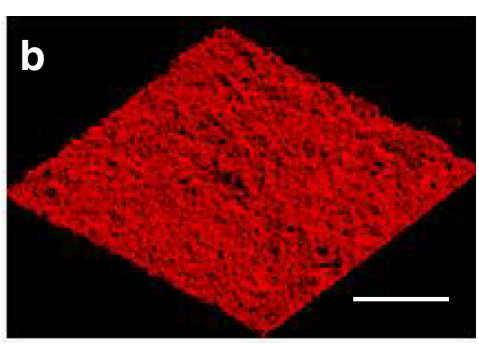

Roseobacter sp. IV3009

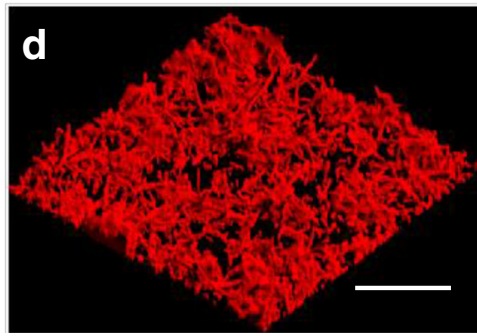

Roseovarius sp. VA014

Fig. 5 Confocal laser scanning microscopy images of single-species biofilms formed after $24 \mathrm{~h}$ of growth on glass surfaces under dynamic conditions. Biofilms were grown on glass surfaces in flow cells, at $22^{\circ} \mathrm{C}$ for $24 \mathrm{~h}$, under a flow of Zobell medium. Bacteria were stained with Syto 61 red. $\mathbf{a}, \mathbf{b}, \mathbf{c}: 3 \mathrm{D}$ views of biofilms of bacterial isolates from mudflat biofilms. $\mathbf{d}$ : 3D view of a biofilm of the bacterial isolate from corrosion product-microorganism composite biofilms. Each image is representative of 10 observations. Scale bar: $67.3 \mu \mathrm{m}$

and 1 from the steel, all being Bacillales). Only 1 strain from each kind of biofilm belonged to the Actinobacteria class. This is consistent with Dang et al. [19], who identified members of Alphaproteobacteria (mainly Rhodobacterales), Gammaproteobacteria (mainly Alteromonadales and Oceanospirillales), and Bacteroidetes (mainly Flavobacteriales) groups, as the most common and dominant surface colonizers in their study.

Out of the 8 Alphaproteobacteria able to build a biofilm on microtiter plates, we finally selected two strains belonging to the Roseobacter clade, Roseobacter sp. IV3009 and Roseovarius sp. VA014, for their capacity to also form a biofilm on glass surface under dynamic conditions. It is well known that the Roseobacter clade members are the dominant and ubiquitous primary surface colonizers whatever the type of surfaces, in temperate coastal waters (Pacific and Atlantic coasts) [5, 10, 11, 19]. Moreover, Dang et al. [19] suggested that Roseobacter were early steel surface colonizers, but also participated to the process of biofilm growth, while Roseovarius would only be pioneer surface colonizers. Roseobacter sp. IV3009 and Roseovarius sp. VA014 are therefore two interesting models of potential pioneering bacteria in marine biofilms.

Among the 5 Gammaproteobacteria able to form a biofilm on polystyrene, 4 were Alteromonadales, with
3 Shewanella and 1 Alteromonas. When Lee et al. [9] studied the succession of bacterial communities during the first $36 \mathrm{~h}$ of biofilm formation on acryl, glass and steel substratum in seawater, they observed that some species of Gammaproteobacteria, such as Alteromonas, were predominant during the first $9 \mathrm{~h}$. Shewanella sp. was until now not described as a predominant bacterium in Atlantic marine biofilms, but was recently observed in early biofilms from Mediterranean Sea [14]. Shewanella sp. IV3014 was selected in this work for its ability to develop an original hairy biofilm with horizontal fibres under dynamic conditions.

We observed a very high diversity among the 6 Flavobacteriia strains able to adhere on polystyrene: they belong to 6 different genera. Previous works showed that bacteria of the Bacteroidetes phylum (containing the Flabovacteriia class) constituted a dominant and diverse bacterial group on carbon steel coupons, at all early immersion stages $[16,19]$, and it was suggested that different strains might be involved at different stages of the surface colonizing and development microbiota [19]. In our work, only one Flavobacteriia strain, Flavobacterium sp. II 2003, was finally able to form a biofilm in dynamic conditions. Both in static and dynamic conditions, Flavobacterium sp. II2003 displayed a very thick biofilm. It is known that pathogenic Flavobacterium species are 


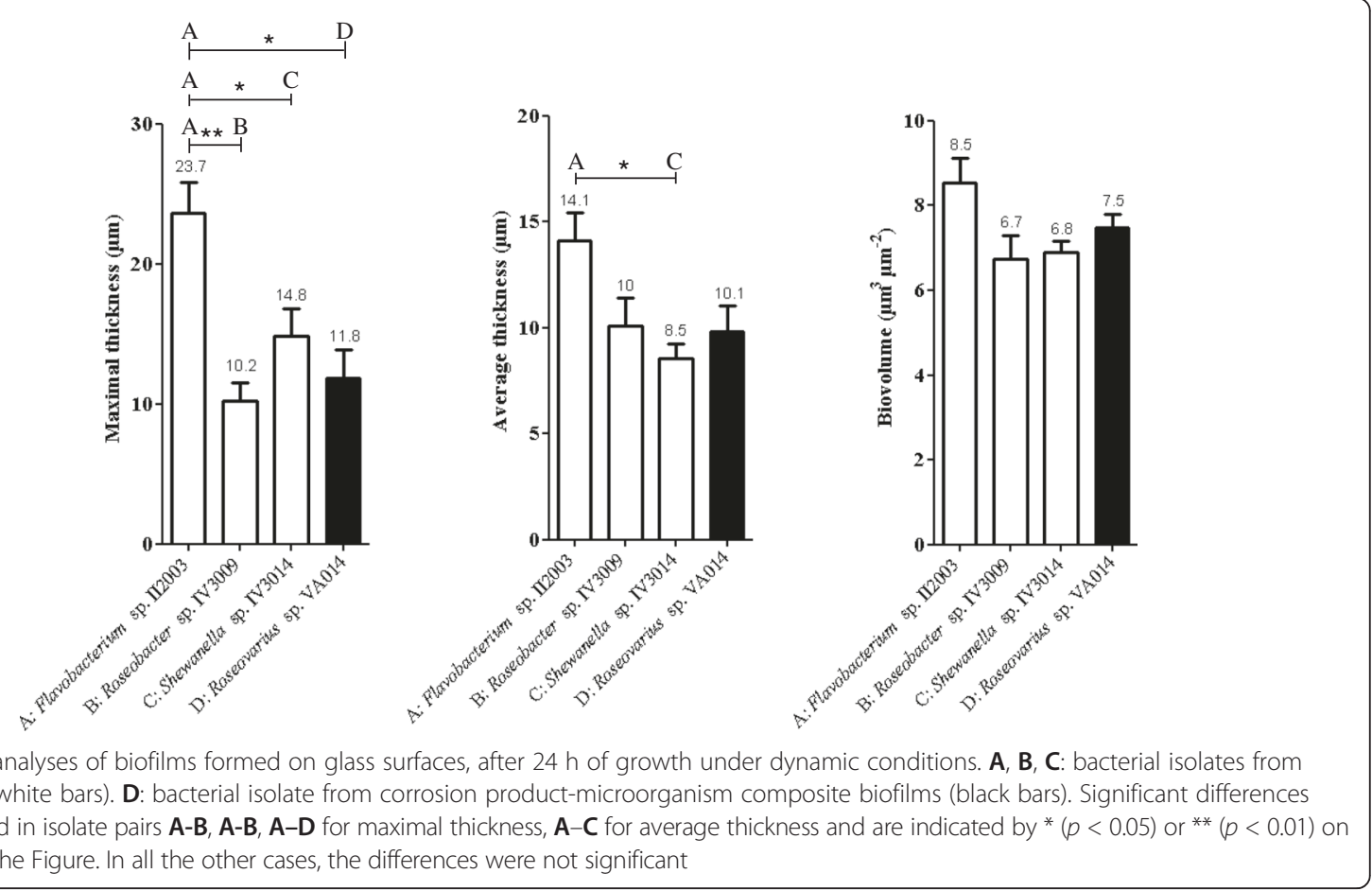

responsible for great losses of fish in aquaculture farming worldwide [20, 21]. Aquaculture surfaces are easily colonized and persisting Flavobacterium sp. inhabiting biofilms might serve as a source of infection or reinfection [20]. Although Flavobacterium sp. are important pathogens in the aquaculture setting and have been detected in industrial, domestic, and medical environment biofilms, the manner in which they form biofilms has not been elucidated [20]. Therefore, the Flavobacterium sp. II2003 strain constitutes a very interesting model.

We detected 4 bacteria affiliated to Firmicutes (Bacillus) able to form biofilms on polystyrene. However, Firmicutes were identified as minor phyla found in biofilms formed on acryl, glass and steel substratum in seawater $[9,10,22]$. In our experiments, the Firmicutes then represent a high proportion compared to what occurs in natural environments. However, none of these strains was able to adhere to glass surfaces and they could not be retained as models. The same phenomenon was observed for the two Actinobacteria strains.

\section{Conclusions}

In conclusion, this work allowed us to finally select four bacteria able to form a thick biofilm on polystyrene as well as glass surface under dynamic conditions: Flavobacterium sp. II2003, Roseobacter sp. IV3009, Shewanella sp. IV3014 from the mudflat biofilm, and Roseovarius sp. VA014 from the corrosion product-microorganism composite biofilm. Moreover, each of the four strains was able to develop a biofilm with a specific 3D structure. It will then be possible to accurately study potential pioneering bacteria in marine biofilms. Primary colonizers are known to be responsible for the initiation of biofouling and may cause various damages in maritime activities and industries. The paramount importance of the bacterial primary colonizers in surface community formation, dynamics, and function needs to be explored. In future studies, we will investigate the interactions between these high forming-biofilm bacterial models and other marine bacteria from the same ecosystems in order to better understand the initial stage of marine biofilm formation.

\section{Methods}

\section{Bacterial strains isolation and culture media}

A wide range of heterotrophic aerobic bacteria (156) was isolated from two marine biofilms. Benthic bacteria were collected from the intertidal temperate mudflat biofilm of Marennes-Oléron Bay $\left(45^{\circ} 55^{\prime} \mathrm{N}, 01^{\circ} 06^{\prime} \mathrm{W}\right.$, Atlantic Coast of France), during three days at low tide in February and July 2008, at $2 \mathrm{~h}, 3 \mathrm{~h}$ and $4 \mathrm{~h}$ after emersion. Mudflat samples were collected using core diameter of $20 \mathrm{~cm}$, and the top 2-3 mm was taken. After sampling, mudflat samples were carried to the laboratory at $4^{\circ} \mathrm{C}$ and immediately processed. The second source of bacteria was the biofilm associated with the corrosion products formed on carbon steel structures immersed in seawater [16]. Briefly, carbon steel coupons $(70 \times 70 \times 6 \mathrm{~mm})$ were immersed in a harbour of La Rochelle (Atlantic coast, 
France) for 1 week to 2 months at a constant depth of 1 $\mathrm{m}$. The steel composition $(98.2 \% \mathrm{Fe}, 0.122 \% \mathrm{C}, 0.206 \%$ Si, 0.641 \% Mn, 0.016 \% P, 0.031 \% S, 0.118 \% Cr, $0.02 \%$ Mo, $0.105 \% \mathrm{Ni}$ and $0.451 \% \mathrm{Cu}$ ) was the same as that of the harbour metallic structures. At the end of the experiment, the corroded coupons were carried to the laboratory in sealed bags filled with seawater and immediately processed. The mudflat samples and biofilms scraped from the corroded coupons were resuspended in sterile artificial seawater (sea salts Sigma $35 \mathrm{~g} \mathrm{l}^{-1}$ ) and inoculated on Marine Agar (Difco) supplemented with cycloheximide (Sigma $100 \mu \mathrm{g} \mathrm{ml}^{-1}$ ) to prevent eukaryotic growth. Bacterial isolates were obtained from the plates after incubation at $20^{\circ} \mathrm{C}$ in aerobic conditions. Strains were conserved as frozen stocks with $25 \%$ glycerol at $-80^{\circ} \mathrm{C}$ until further processing. For all subsequent tests, the strains were grown in Zobell broth (pastone Bio-Rad 4. $\mathrm{g}^{-1}$; yeast extract Bio$\operatorname{Rad} 1 \mathrm{~g} \mathrm{l}^{-1}$; sea salts Sigma $30 \mathrm{~g} \mathrm{l}^{-1}$ ) at $22^{\circ} \mathrm{C}$ with shaking (150 rpm).

\section{DNA extraction and 16S rRNA gene sequencing}

The isolated bacterial strains were identified by $16 \mathrm{~S}$ rRNA gene sequencing. The genomic DNA of bacteria was extracted with the Genomic DNA from Tissue Kit (Macherey Nagel) from 1 to $5 \mathrm{ml}$ of overnight culture. Amplification of about $1400 \mathrm{bp}$ of the 16S rRNA gene was carried out using $50 \mathrm{ng}$ of genomic DNA in a total volume of $50 \mu \mathrm{l}$. The reaction mixtures contained 0.2 $\mu \mathrm{mol} \mathrm{l}^{-1}$ 16SUnivf ( ${ }_{5}$,AGAGTTTGATCCTGGCTCA ${ }_{3}$ ) and 16SUnivR ( ${ }_{5}$, GGCTACCTTGTTACGACTT $_{3}$ ) primers, $3 \mathrm{mmol} \mathrm{l}^{-1} \mathrm{MgCl}_{2}, 320 \mu \mathrm{mol} \mathrm{l}^{-1}$ of each dNTP, and 0.04 Taq polymerase Units (Fermentas), in the corresponding $1 \times$ buffer. Denaturation at $95^{\circ} \mathrm{C}$ for 2 min was followed by 30 cycles of amplification $\left(92^{\circ} \mathrm{C}\right.$ for $30 \mathrm{~s}, 54^{\circ} \mathrm{C}$ for $30 \mathrm{~s}, 72^{\circ} \mathrm{C}$ for $1 \mathrm{~min} 30$ ). About $300 \mathrm{ng}$ of each amplified DNA were sent to GenoScreen (Lille, France) for sequencing. The $16 \mathrm{~S}$ rDNA sequences were compared with those in GenBank using the Blast software (National Institutes of Health, USA).

\section{Growth of biofilm on polystyrene surfaces (microtiter plates) under static conditions, crystal violet staining} The ability of the bacterial strains to form biofilms onto polystyrene was tested individually by cultivating each of them in 96-well microtiter plates (MICROTEST ${ }^{\mathrm{rm}}$ 96, Falcon) under static conditions and by crystal violet staining. The protocol used was a modified version of that described by O'Toole and Kolter [23]. Cells of an overnight bacterial culture were resuspended after 10 min of centrifugation at $7000 \mathrm{~g}$ in artificial seawater to a final optical density at $600 \mathrm{~nm}\left(\mathrm{OD}_{600}\right)$ of 0.25 and 150 $\mu \mathrm{l}$ of the resulting bacterial suspensions were loaded per well of the microtiter plates. After incubation for $2 \mathrm{~h}$ at $22^{\circ} \mathrm{C}$, the wells were gently washed three times with artificial seawater. Thereafter, $150 \mu \mathrm{l}$ of Zobell medium were transferred in each well and the plate was incubated at $22^{\circ} \mathrm{C}$ for $24 \mathrm{~h}$. The planktonic fractions were transferred into a new microtiter plate and the absorbance was measured at $600 \mathrm{~nm}$. The plates with biofilms were washed three times with artificial seawater. The biofilms were then stained with a $0.8 \%$ crystal violet solution for $20 \mathrm{~min}$. The wells were then rinsed with ultrapure water until the wash-liquid was clear (10 times on average) and $150 \mu \mathrm{l}$ of $96 \%$ ethanol was added to solubilize the attached crystal violet from biofilms. Quantification was carried out by measuring the $\mathrm{OD}_{595}$. To be able to compare the results obtained with strains showing different growth speeds, the biofilm formation was expressed as the ratio of $\mathrm{OD}_{595}$ (cells grown in biofilm)/OD 600 (planktonic cells). Assays were performed in triplicate for each strain.

\section{Growth of biofilm on glass surfaces under static conditions, fluorescence microscopy and image analyses} For each tested strain, cells of an overnight bacterial culture were resuspended after $10 \mathrm{~min}$ of centrifugation at $7000 \mathrm{~g}$ in artificial seawater to a final $\mathrm{OD}_{600}$ of 0.25 . One $\mathrm{ml}$ of the resulting bacterial suspension was loaded in a compartment of Petri dishes (CellView diameter $35 \mathrm{~mm}$, Greiner Bio-one) containing four compartments and a glass bottom. After incubation for $2 \mathrm{~h}$ at $22^{\circ} \mathrm{C}$, the compartments were gently washed with artificial seawater and $1 \mathrm{ml}$ of Zobell medium was poured in each compartment. Biofilms were then grown for $24 \mathrm{~h}$ at $22^{\circ} \mathrm{C}$. The surfaces were then rinsed with artificial seawater and biofilms were stained with $4 \mu \mathrm{g} \mathrm{l}^{-1} 4$-6-diamidino-2-phenylindole (DAPI) in the dark for $20 \mathrm{~min}$. After rinsing with ultra-pure water and drying, samples were analysed using a fluorescence microscope DMI6000B system (magnification 1000×, Leica Microsystems, Germany), over an average of 10 fields. The three dimensional (3D) structures were reconstituted by using IMARIS software. The percentages of colonized surface (\%) were calculated using the NIH ImageJ software [24]. All experiments were performed in triplicate.

\section{Growth of biofilm on glass surface under dynamic conditions in three channel flow cell, confocal laser scanning microscopy and image analyses}

Bacterial biofilms were grown on glass slides in threechannel flow cells (channel dimensions 1 by 4 by 40 $\mathrm{mm}$, Technical University of Denmark Systems Biology, Denmark) [25]. The flow system was assembled, prepared and sterilized as described by Tolker-Nielsen and Sternberg [26]. The substratum consisted in a microscope glass coverslip $(24 \times 50$ st1, KnittelGlasser, Germany). Flow cells were inoculated with overnight bacterial cultures diluted in artificial seawater to a final 
$\mathrm{OD}_{600}$ of 0.1 . Bacteria were allowed to attach during $2 \mathrm{~h}$ at $22^{\circ} \mathrm{C}$ without medium flow. The channels were then washed by applying a flow of artificial seawater for 15 min at a rate of $2 \mathrm{ml} \mathrm{h}^{-1}$ to remove planktonic cells. Biofilm growth was then performed under a constant flow of Zobell $\left(2 \mathrm{ml} \mathrm{h}^{-1}\right)$ for $24 \mathrm{~h}$ at $22^{\circ} \mathrm{C}$. Microscopic observations were performed by confocal laser scanning microscopy using a TCS-SP2 system (Leica Microsystems, Germany). The 2-h attached cells and the biofilms formed after $24 \mathrm{~h}$ on the glass surface were observed by staining bacteria with $5 \mu \mathrm{mol} \mathrm{l}^{-1}$ Syto $61 \mathrm{red}$. Images were obtained using the Leica confocal software. The surface coverages after the $2 \mathrm{~h}$ adhesion step were evaluated using the ImageJ software. The biofilm stacks were analysed with the COMSTAT software (developed in MATLAB, [27]) to estimate the maximal and average thicknesses $(\mu \mathrm{m})$ and the biovolume $\left(\mu \mathrm{m}^{3} \mu \mathrm{m}^{-2}\right)$. The values were calculated from three independent experiments from which a total of 15 image stacks were obtained.

\section{Statistical analyses}

The standard deviations were calculated using Matlab software (Mathworks Inc., Natick, USA). The statistical analyses were determined by the Student $t$-test and considered as significant if $p$ values are $<0.05$.

\section{Competing interests}

The authors declare that they have no competing interests.

\section{Authors' contributions}

ID designed the experimental work, conducted data analysis, participated in writing the manuscript. SR, AB, AD, DA and VS participated in experimental work and helped to draft the manuscript. IL and SS collected the samples, participated in experimental work, supervised the laboratory work and participated in writing the manuscript and in organizing the project. All authors read and approved the final manuscript.

\section{Acknowledgements}

The authors wish to thank the Conseil Général de la Charente Maritime (France) for the PhD grant of Ibtissem Doghri. This work was financially supported by the CNRS "Ecosphère Continentale et Côtière" program 2013-14 (France). The LIENSs and LBCM are supported by the Région Poitou-Charentes (France), the Région Bretagne (France) and the European FEDER funds.

\section{Author details}

${ }^{1}$ Université de La Rochelle, UMR 7266 CNRS-LIENSs, Bât. Marie Curie, Av. Michel Crépeau, 17042, La Rochelle cedex 01, France. ${ }^{2}$ Université de Bretagne-Sud, EA 3884, LBCM, IUEM, 56100, Lorient, France.

Received: 24 March 2015 Accepted: 15 October 2015

Published online: 24 October 2015

\section{References}

1. Costerton JW, Stewart PS, Greenberg EP. Bacterial biofilms: a common cause of persistent infections. Science. 1999;284:1318-22.

2. Salta M, Wharton JA, Blache Y, Stokes KR, Briand JF. Marine biofilms on artificial surfaces: structure and dynamics. Environ Microbiol. 2013;15:2879-93.

3. Karatan E, Watnick P. Signals regulatory network and materials that build and break bacterial biofilms. Microbiol Mol Biol Rev. 2009;73:310-47.

4. Jefferson KK. What drives bacteria to produce a biofilm? FEMS Microbiol Lett. 2004;236:163-73.
5. Dang H, Lovell CR. Bacterial primary colonization and early succession on surfaces in marine waters as determined by amplified rRNA gene restriction analysis and sequence analysis of 165 rRNA genes. Appl Environ Microbiol. 2000;66:467-75.

6. Davey ME, O'Toole GA. Microbial biofilms: from ecology to molecular genetics. Microbiol Mol Biol Rev. 2000;64:847-67.

7. Stoodley P, Sauer K, Davies DG, Costerton JW. Biofilms as complex differentiated communities. Annu Rev Microbiol. 2002;56:187-209.

8. Huggett M, Nedved B, Hadfield M. Effects of initial surface wettability on biofilm formation and subsequent settlement of Hydroides elegans. Biofouling. 2009;25:387-99.

9. Lee JW, Nam JH, Kim YH, Lee KH, Lee DH. Bacterial communities in the initial stage of marine biofilm formation on artificial surfaces. J Microbiol. 2008;46:174-82.

10. Jones PR, Cottrell M, Kirchman DL, Dexter SC. Bacterial community structure of biofilms on artificial surfaces in an estuary. Microb Ecol. 2007;53:153-62.

11. Dang H, Li T, Chen M, Huang G. Crossocean distribution of Rhodobacterales bacteria as primary surface colonizers in temperate coastal marine waters. Appl Environ Microbiol. 2008;74:52-60.

12. Dang $\mathrm{H}$, Lovell CR. Numerical dominance and phylotype diversity of marine Rhodobacter species during early colonization of submerged surfaces in coastal marine waters as determined by 165 ribosomal DNA sequence analysis and fluorescence in situ hybridization. Appl Environ Microbiol. 2002;68:496-504.

13. Webster NS, Smith LD, Heyward AJ, Watts JEM, Webb RI, Blackall LL, et al. Metamorphosis of a scleractinian coral in response to microbial biofilms. Appl Environ Microbiol. 2004;70:1213-21.

14. Brian-Jaisson F, Ortalo-Magné A, Guentas-Dombrowsky L, Armougom F, Blache $Y$, Molmeret M. Identification of bacterial strains isolated from the Mediterranean sea exhibiting different abilities of biofilm formation. Microb Ecol. 2014;68:94-110.

15. Douillet P. Bacterivory in Pacific oyster Crassostrea gigas larvae. Mar Ecol Prog Ser. 1993;98:123-34

16. Lanneluc I, Langumier M, Sabot $R$, Jeannin M, Refait $P$, Sablé $S$. On the bacterial communities associated with the corrosion product layer during the early stages of marine corrosion of carbon steel. Int Biodeterior Biodegrad. 2015:99:55-65.

17. Klausen M, Gjermansen M, Kreft J-U, Tolker-Nielsen T. Dynamics of development and dispersal in sessile microbial communities: examples from Pseudomonas aeruginosa and Pseudomonas putida biofilms. FEMS Microbiol Lett. 2006:261:1-11.

18. Barken KB, Pamp SJ, Yang L, Gjermansen M, Bertrand JJ, Klausen M, et al. Roles of type IV pili, flagellum-mediated motility and extracellular DNA in the formation of mature multicellular structures in Pseudomonas aeruginosa biofilms. Environ Microbiol. 2008;10:2331-43.

19. Dang $H$, Chen $R$, Wang L, Shao S, Dai L, Ye Y, et al. Molecular characterization of putative biocorroding microbiota with a novel niche detection of Epsilonand Zetaproteobacteria in Pacific Ocean coastal seawaters. Environ Microbiol. 2011;13:3059-74.

20. Basson A, Flemming LA, Chenia HY. Evaluation of Adherence, Hydrophobicity, Aggregation, and Biofilm Development of Flavobacterium johnsoniae-Like Isolates. Microb Ecol. 2008;55:1-14.

21. Starliper EC. Bacterial coldwater disease of fishes caused by Flavobacterium psychrophilum. J Adv Res. 2011;2:97-108.

22. Chung $H$, Lee $O$, Huang $Y$, Mok S, Kolter R, Qian P. Bacterial community succession and chemical profiles of subtidal biofilms in relation to larval settlement of the polychaete Hydroides elegans. ISME J. 2010;4:817-28.

23. O'Toole GA, Kolter R. Initiation of biofilm formation in Pseudomonas fluorescens WCS365 proceeds via multiple, convergent signalling pathways: a genetic analysis. Mol Microbiol. 1998;28:449-61.

24. Rasband WS. ImageJ, U.S. National Institutes of Health, Bethesda, Maryland, USA, imagej.nih.gov/ij/, 1997-2012

25. Pamp SJ, Sternberg C, Tolker-Nielsen T. Insight into the microbial multicellular lifestyle via flow-cell technology and confocal microscopy. Cytometry A. 2009;75:90-103.

26. Tolker-Nielsen T, Sternberg C. Growing and analyzing biofilms in flow chambers. Curr Protoc Microbiol. 2011;2:1-17.

27. Heydorn A, Nielsen AT, Hentzer M, Sternberg C, Givskov M, Ersbøll BK, et al. Quantification of biofilm structures by the novel computer program COMSTAT. Microbiology. 2000;146:2395-407. 